\title{
Mitigasi Bencana Dalam Peningkatan Kewaspadaan Terhadap Ancaman Gempa Bumi Di Universitas Andalas
}

\author{
${ }^{1}$ Nursyabani, ${ }^{2}$ Roni Ekha Putera, ${ }^{3}$ Kusdarini \\ 123Jurusan Admnistrasi Publik, Universitas Andalas, Kota Padang, Indonesia
}

\begin{abstract}
This study aims to describe and analyze how the implementation and process of earthquake disaster mitigation at Universitas Andalas. This research was motivated by the high risk of earthquake disasters at Universitas Andalas and the still low education and understanding of students and academic aspirations of disaster mitigation. So it is necessary to optimize mitigation activities in the Universitas Andalas campus area. This is in accordance with Law Number 24 of 2007 concerning Disaster Management and the Tridarma of Higher Education which has a strategic role in disaster management, especially in relation to learning, research and community service. The method used in this research is descriptive qualitative, data collection techniques using interviews and documentation. To test the authenticity of the data obtained in the field, researchers used source triangulation techniques. The selection of informants was done by purposive sampling. As for the results of this study, in general, disaster mitigation activities in increasing awareness of the threat of an earthquake in Universitas Andalas have not run optimally. This is evidenced by the implementation of several activities that failed to achieve the target in the form of increased disaster alertness and increased understanding of students and academics on disaster mitigation, the absence of regulations containing the implementation of disaster mitigation activities at Universitas Andalas. Lack of involvement of external organizations in implementing disaster mitigation activities, as well as limited human resources and budget in implementing disaster mitigation activities. The results showed that the alternative policy was chosen based on the criteria for selecting the alternative policy: 1) Technical feasibility, it was found that the purpose of establishing KEK was as a forum for ecraf's actors. 2) Economic and financial, KEK doesn't receive any special funds and no goals have been achieved. 3) Political viability, this policy doesn't contradicting with the applicable regulations. 4) Administrative Operability policy is realistic, but the support from the nine offices has not been maximal. 5) The criteria chosen are based on the success of the other regions and then it is adopted. It is the main criteria in the process of selecting and determining KEK as an alternative policy for the development of creative economy potentian in Banyumas Regency
\end{abstract}

Keywords: Disaster Mitigation, Andalas University Disaster Study Center, Andalas University Student Disaster Preparedness Committee

\begin{abstract}
Abstrak
Penelitian ini bertujuan untuk mendeskripsikan dan menganalisis bagaimana penerapan dan proses mitigasi bencana gempa bumi di Universitas Andalas. Penelitian ini dilatarbelakangi oleh tingginya resiko bencana gempa bumi di Universitas Andalas dan masih rendahnya pendidikan serta pemahaman mahasiswa dan citivitas akademika terhadap mitigasi bencana. Sehingga diperlukan pengoptimalan kegiatan mitigasi di kawasan kampus Universitas Andalas. Hal ini sesuai dengan Undang-Undang Nomor 24 Tahun 2007 tentang Penanggulangan Bencana dan Tridarma Perguruan Tinggi yang memiliki peran strategis dalam penanggulangan bencana, terutama berkaitan dengan pembelajaran, penelitian dan pengabdian masyarakat. Metode yang digunakan dalam penelitian ini adalah deskriptif kualitatif, teknik pengumpulan data menggunakan wawancara dan dokumentasi. Untuk menguji keabshana data yang didapat dilapangan peneliti menggunakan teknik triangulasi sumber. Pemilihan informan dilakukan dengan purposive sampling. Adapun hasil dari penelitian ini
\end{abstract}


yaitu secara umum kegiatan mitigasi bencana dalam peningkatan kewaspadaan terhadap ancama gempa bumi di Unand belum berjalan optimal. Hal tersebut dibuktikan dengan pelaksanaan beberapa kegiatan yang tidak dapat mencapai sasaran berupa adanya peningkatan kewaspadaan bencana serta peningkatan pemahaman mahasiswa dan civitas akademika terhadap mitigasi bencana, tidak adanya regulasi yang memuat pelaksanaan kegiatan mitigasi bencana di Universitas Andalas. Kurangnya keterlibatan organisasi luar dalam pelaksanaan kegiatan mitigasi bencana, serta terabatasnya sumber daya manusia dan anggaran dalam pelaksanaan kegiatan mitigasi bencana.

Kata kunci: Mitigasi Bencana, Pusat Studi Bencana Universitas Andalas, Komite Siaga Bencana Mahasiswa Universitas Andalas

*)Penulis Korespondensi

E-mail : roniekhaputera@soc.unand.ac.id

\section{PENDAHULUAN}

Bencana merupakan peristiwa atau rangkaian peristiwa yang mengacam dan menganggu kehidupan dan penghidupan masyarakat yang disebabkan baik oleh faktor alam dan atau faktor non alam maupun faktor manusia, sehingga mengakibatkan timbulnya korban jiwa manusia, kerusakan lingkungan, kerugian harta benda, dan dampak psikologis. Ketidaksiapan dalam menghadapi bencana, terutama di daerah yang bernilai ekonomi tinggi akan menimbulkan kerugian yang sangat besar.

Pada tabel $1.1 \mathrm{di}$ atas bencana yang banyak merenggut jiwa yaitu bencana gempa bumi dan tsunami di Aceh pada tahun 2004 dengan jumlah korban meninggal dunia 126.000 jiwa dan 30.000 jiwa dinyatakan hilang . Bencana gempa bumi dan tsunami di Aceh menimbulkan korban jiwa yang tidak sedikit, serta duka mendalam bagi Indonesia. Pada tahun 2009 bencana gempa bumi di Sumatera Barat juga banyak menimbulkan korban jiwa.

Banyaknya korban jiwa yang diakibatkan oleh bencana terutama gempa bumi, maka diperlukan pengurangan risiko bencana.
Berdasarkan konferensi dunia tentang upaya pengurangan risiko bencana pada tahun 2015 menghasilkan Kerangka Kerja Sendai tahun 2015-2030. Konferensi tersebut mengadopsi 4 prioritas tindakan sebagai berikut : (1) Memahami risiko bencana, (2) Penguatan tata kelola risiko bencana untuk mengelola risiko bencana, (3) Investasi dalam pengurngan risiko bencana untuk ketahanan, (4) Meningkatkan kesiapsiagaan bencana untuk respon yang efektif dan untuk membangun kembali lebih baik dalam pemulihan, rehabilitas dan rekonstruksi. Salah satu prioritas tindakan dalam Kerangka Kerja Sendai adalah tentang kesiapsiagaan bencana. Untuk meminimalisir terjadinya korban baik jiwa maupun harta benda maka diperlukan masyarakat yang siap siaga terhadap potensi bencana di daerah yang rawan bencana gempa bumi dan tsunami.

Hasil penelitian Ikatan Ahli Kebencanaan Indonesia (IAKI) juga menyatakan bahwa Kota Padang salah satu kota yang rawan terjadinya bencana gempa bumi. Dengan tingginya dampak yang akan ditimbulkan oleh bencana gempa bumi maka secara keseluruhan, dalam 
upaya pengurangan risiko bencana maka perlu dilakukan langkah-langkah mitigasi dan kesiapsiagaan kepada masyarakat dimulai dengan meningkatkan pemahaman masyarakat, peningkatan infrastruktur, sarana sosialisasi dan peringatan dini serta arahan pada masyarakat perlu ditingkatkan.

Perguruan Tinggi melalui Tridarmanya memiliki peran strategis dalam penanggulangan bencana, terutama berkaitan dengan pembelajaran, penelitian dan pengabdian masyarakat. Pelaksanaan peran tersebut berlangsung dengan pertisipasi aktif dosen dan mahasiswa melalui berbagai program dan kegiatan, baik secara internal maupun eksternal. Serta Perguruan Tinggi memiliki Jaringan komunikasi dan informasi yang luas dan dapat dimanfaatkan sewaktu mobilisasi dan mitigasi penanggulangan bencana.

Pendidikan kebencanaan perlu dikembangkan oleh Perguruan Tinggi terutama yang berada pada lokasi rawan bencana. Pendidikan Kebencanaan bertujuan untuk mengurangi risiko akibat bencana antara lain potensi terjadinya bencana dan sejarah bencana yang pernah terjadi pada wilayah tersebut, bentuk antisipasi, meningkatkan pengetahuan dan kesadaran terhadap tanda-tanda bencana, dampak bagi individu, keluarga dan komunitas, cara penanganan dalam kondisi bencana, cara menyelamatkan diri cara bertahan hidup dalam situasi bencana. Mitigasi bencana menurut

Peraturan Pemerintah Republik Indonesia Nomor 21 Tahun 2008 Tentang Penyelenggaraan Penanggulangan Bencana adalah salah satu cara atau tindakan untuk mengurangi risiko bencana, baik melalui pembangunan fisik maupun penyadaran serta peningkatan kemampuan dalam menghadapi ancaman bencana. Mitigasi bencana dibagi dua yaitu mitigasi yang bersifat struktural dan nonstruktural. Untuk mitigasi nonstruktural adalah metode atau upaya mengurangi risiko dampak bencana dengan cara memberdayakan dan memberikan pengetahuan yang baik kepada masyarakat.

Universitas Andalas sudah melakukan kegiatan mitigasi dalam peningkatan ancaman bencana gempa bumi di kawasan Universitas Andalas itu sendiri dengan adanya ramburambu di setiap gedung perkuliahan, gedung rektorat, namun untuk gedung fakultas dan jurusan belum semuanya memiliki rambu-rambu jalur evakuasi. Disamping itu Universitas juga berperan penting dalam upaya penanggulangan bencana. Universitas Andalas juga telah melakukan upaya untuk meningkatkan kesiapsiagaan dan mitigasi mahasiswa, dosen dan beserta karyawan dalam menghadapi gempa bumi yang bertujuan untuk mengurangi risiko dari dampak bencana tersebut. Salah bentuk kegiatan yang dilakukan Universitas Andalas yaitu dengan mengadakan simulasi gempa bumi dan tsunami pada tanggal 26 April 2019.

Mitigasi nonstruktural W.N Carter membaginya dalam beberapa kegiatan , beberapa diantaranya adalah pembentukkan kerangka hukum, pembentukkan kelembagaan dengan tujuan membangun institusi atau kelompok-kelompok organisasi yang berasal dari masyarakat agar sadar bencana. Sesuai dengan teori tersebut Universitas Andalas memiliki beberapa kelompok organisasi yang dibentuk oleh Universitas Andalas yang memiliki tugas dan fungsi sebagai perpanjangan tangan Perguruan Tinggi dalam melakukan penanggulangan bencana. 
Tabel 1. Beberapa Kejadian Bencana Alam Gempa Bumi dan Tsunami Yang Pernah Terjadi di Indonesia

\begin{tabular}{|l|l|l|}
\hline \multicolumn{1}{|c|}{ Nama Kejadian } & \multicolumn{1}{c|}{ Tanggal Kejadian } & \multicolumn{1}{c|}{ Korban Jiwa } \\
\hline Gempa \& Tsunami Aceh & 26 Des 2004 & $\begin{array}{l}\text { 126.000 meninggal } \\
30.000 \text { hilang }\end{array}$ \\
\hline Gempa Nias & 28 Mar 2005 & $\begin{array}{l}\text { 658 meninggal } \\
\text { 3.277 luka-luka }\end{array}$ \\
\hline Gempa Sumbar & 30 Sept 2009 & 6.234 meninggal \\
\hline Gempa \& Tsunami Pagai & 25 Okt 2010 & 456 meninggal \\
\hline Gempa \& Tsunami Lombok & 5 Agus 2018 & $\begin{array}{l}\text { 464 meninggal } \\
829 \text { luka-luka }\end{array}$ \\
\hline Tsunami Selat Sunda & 22 Des 2018 & $\begin{array}{l}\text { 437 meninggal } \\
1.485 \text { luka-luka }\end{array}$ \\
\hline Gempa Ambon & 26 Sept 2019 & 150 luka-luka \\
\hline
\end{tabular}

Universitas Andalas memiliki lembaga Pusat Studi Bencana atau yang disingkat dengan PSB. PSB merupakan lembaga yang melakukan kegiatan dan bekerja sama dengan pihak-pihak terkait pergurangan risiko bencana seperti pemerintah, organisasi kebencanaan, dan pihak lain yang tergabung dalam forum Pengurangan Risiko Bencana (PRB) kota Padang dan Provinsi Sumatera Barat. Dalam meningkatkan kesadaran mitigasi bencana di lingkungan Unand, PSB sering mengadakan berbagai acara seminar yang bertemakan kebencanaan. Acara-acara tersebut selain melibatkan institusi pemerintah dan LSM yang fokus di bidang bencana alam, juga selalu melibatkan mahasiswa itu sendiri. Hal ini tentu agar para mahasiswa memperoleh pemahaman dan pengetahuan yang lebih mengenai kebencanaan.

Selain lembaga studi yang concern di seputar permasalahan kebencanaan, di dalam lingkup lampus Unand juga terdapat organisasi kemahasiswaan yang sifatnya tanggap bencana, yaitu HET (Hipporactes Emergency Team) dan Komite Siaga Bencana Mahasiswa (KOSBEMA). 2 organisasi inilah yang berperan dalam kegiatan mitigasi di kawasan kampus Unand. HET merupakan organisasi yang berasal dari fakultas kedokteran, anggotanya pun juga terdiri dari mahasiswa kedokteran.

Mitigasi ini mencakup langkahlangkah regulasi, program pendidikan, modifikasi perilaku serta pengendalian lingkungan. Untuk melaksanakan mitigasi bencana yang baik tidak hanya membutuhkan kesadaran dari mahasiswa itu saja, melainkan juga dibutuhkan pengetahuan dan kesadaran terkait manajemen bencana misalnya dengan memahami bagaimana menerapkan langkahlangkah mitigasi. Untuk itu dalam mewujudkannya dibutuhkan pelatihan dan pendidikan kepada mahasiswa dengan cara memasukkan materi kebencaan dalam matakuliah, agar mahasiswa memahami bagaimana manajemen bencana yang semestinya. Di Universitas Andalas belum semua fakultas memiliki mata kuliah tentang kebencanaan.

Dalam penelitian ini peneliti hanya fokus mengkaji mitigasi dari aspek non struktural, karena kajian tersebut lebih sesuai dengan bidang kajian ilmu sosial. Untuk metode mitigasi struktural lebih berfokus 
kepada bangunan fisik misalnya dengan melakukan perencanaan dan perancangan kota (Planning and Resign For Safe City) yang komprehensif, dan kajian mitigasi struktural lebih tepat dikaji oleh ilmu eksakta. Sehingga peneliti lebih berfokus mengkaji melalui metode non struktural. Oleh karena itu peneliti tertarik untuk melakukan penelitian terhadap mitigasi bencana dalam peningkatan kewaspadaan terhadap ancaman gempa bumi di Universitas Andalas. Mengingat bahwa masih rendahnya pendidikan dan pemahaman mahasiswa terhadap mitigasi bencana.

\section{METODE PENELITIAN}

Penelitian ini menggunakan pendekatan kualitatif dan jenis penelitian ini adalah penelitian deskriptif kualitatif yaitu menggambarkan atau melukiskan secara sistematis, faktual dan akurat mengenai fakta-fakta, sifat-sifat serta hubungan yang diselidiki. Teknik pengumpulan data dalam penelitian ini adalah teknik purposive sampling. Unit analisis dalam penelitian ini adalah lembaga dan teknik keabsahan data dengan menggunakan teknik triangulasi.

\section{HASIL DAN DISKUSI/ANALISIS}

Dalam kajian ini, peneliti akan mendeskripsikan mitigasi bencana dalam peningkatan kewaspadaan terhadap ancaman gempa bumi di Universitas Andalas menggunakan teori Mitigasi Nonstrukturak oleh William Nick Carter. Mitigasi Nonstruktural menurut William Nick Carter terdapat 6 variabel yaitu :

1. Kerangka Hukum

Menurut W.N Carter mitigasi nonstruktural dapat dilakukan dengan menyediakan kebijakan atau kerangka hukum sebagai pedoman atau landasan hukum yang bersifat mengikat dalam melakukan mitigasi. Peraturan atau kebijakan merupakan alat administrasi publik untuk aktor, organisasi, dan sumberdaya lainnya untuk diorganisasikan secara bersama-sama untuk menjalankan peraturan yang telah dibuat, atau dengan kata lain menjadikan kebijakan tersebut sebagai pedoman dalam menjalankan kegiatan.

Secara umum kerangka hukum
atau kebijakan mengenai
penanggulangan bencana di
Indonesia telah diatur dalam UndangUndang Republik Indonesia Nomor 24 Tahun $2007 \quad$ Tentang Penanggulangan Bencana, dimana pada undang-undang tersebut telah diatur segala hal tentang penanggulangan bencana. Kebijakan lainnya ada Peraturan Pemerintah Republik Indonesia Nomor 21 Tahun 2008 tentang Penyelenggaraan Penanggulangan Bencana, salah satunya adalah kegiatan mitigasi.

Namun sangat disayangkan Pemerintah masih belum membuat regulasi dan aturan yang jelas terkait program mitigasi bencana di tingkat perguruan tinggi. Begitu pula pihak Unand juga belum memiliki aturan atau kebijakan tentang mitigasi. Hal ini membuat beberapa fakultas punya kebijakan yang berbeda mengimplementasikan program mitigasi bencana.

\section{Pembentukkan Kelembagaan}

Menurut W.N Carter peranan kelembagaan dalam mitigasi bencana memiliki nilai strategis untuk menciptakan mekanisme mitigasi yang terstruktur dan terpadu. Kelembagaan adalah suatu tatanan atau pola hubungan antara anggota masyarakat atau organisasi yang saling mengikat yang dapat menentukan bentuk hubungan antara manusia atau antara organisasi yang diwadahi dalam suatu organisasi atau 
jaringan. Dalam kelembagaan terdapat faktor-faktor pembatas dan pengikat berupa norma, kode etik atau aturan formal atau informal untuk mengendalikan perilaku social dalam bekerja sama untuk mencapai tujuan bersama.

$\begin{array}{crr}\text { Unand memiliki beberapa } & \text { bang bergerak di }\end{array}$ kebencanaan, yang pertama yaitu Pusat Studi Bencana (PSB) merupakan lembaga yang melakukan kegiatan dan bekerja sama dengan pihak-pihak terkait pengurangan risiko bencana seperti pemerintah, organisasi kebencanaan, dan pihak lain yang tergabung dalam forum Pengurangan Risiko Bencana (PRB) Kota Padang dan Provinsi Sumatera Barat.

Yang kedua yaitu Komite Siaga Bencana Mahasiswa (KOSBEMA). Mengingat terbatasnya sumber daya manusia yang di miliki oleh PSB maka keberadaan KOSBEMA dimanfaatkan sebagai perpanjangan tangan PSB dalam memberikan sosialisasi dan simulasi terkait kebencaan kepada mahasiswa di Universitas Andalas.

Yang terakhir lembaga dalam linkup Unand yang cocern di bidang mitigasi bencana adalah Hippocrates Emergency Team (HET). Organisasi yang satu ini berada di bawah Fakultas Kedokteran. HET telah proaktif menjai organisasi siaga bencana. Mereka terjun ke berbagai lokasi bencana sebagai tenaga medis dan tim pencari korban.

3. Kesadaran Masyarakat

Dalam melaksanakan kegiatan mitigasi bencana dibutuhkan kesadaran masyarakat dalam mendukung kegiatan atau program mitigasi yang dilakukan pemerintah. Selain adanya kerangka hukum yang kuat untuk dijadikan pedoman dalam melakukan kegiatan mitigasi, serta tersedianya forum atau lembaga yang bertanggungjawab atas kegiatan penanggulangan bencana juga dibutuhkan kesadaran masyarakat terhadap upaya penanggulangan bencana, salah satunya adalah mitigasi. Maka dari itu dibutuhkan kesadaran masyarakat kampus khususnya mahasiswa dan civitas akademika untuk berpatisipasi pada setiap kegiatan penanggulangan bencana salah satunya dengan terlibat dalam kegiata mitigasi. Keterlibatan mahasiswa dimaksud disini meliputi :

a. Pemahaman atau Pengetahuan Civitas Akademika untuk Kerentanan Potensi Bahaya Wilayah

Secara umum mahasiswa yang berada di kawasan kampus Unand tidak memahami bahwa mereka berada pada kawasan wilayah yang memiliki resiko bencana gempa bumi, mereka meganggap bahwa kampus unand berada pada zona aman bencana gempa bumi dan tsunami. Menyikapi hal tersebut, para akademisi Universitas Andalas berinisiatif memasukkan materi kebencanaan dalam mata kuliah wajib dan pilihan bagi para mahasiswa. Namun, hal tersebut hanya diaplikasikan oleh sebagian fakultas dan program studi yang membutuhkan materi kebencaan. Efeknya, pengetahuan akan kerentanan potensi bencana wilayah tidak merata pada setiap mahasiswa.

b. Pemahaman Terhadap LangkahLangkah Mitigasi dan Penerapannya

Dalam melaksanakan mitigasi bencana terlebih dahulu dibutuhkan pemahaman masyarakat atau mahasiswa terhadap langkah-langkah apa saja yang perlu dilakukan dalam melaksanakan mitigasi. Agar tujuan mitigasi sebagai upaya mengurangi resiko bencana dapat berjalan dengan baik dengan semestinya. Harapannya ketika mahasiswa atau masyarakat dapat menerapkan mitigasi dengan baik dan dilakukan secara mandiri. Di 
kampus Universitas Andalas peneliti masih melihat banyak masyarakat selama ini yang belum memahami bagaimana langkah-langkah mitigasi, salah satunya dengan memanfaatkan tanda-tanda alam sebagai sistem peringatan dini ketika terjadinya gempa bumi kemudian untuk saat ini sudah banyak program yang dijalankan oleh Unand maupun lembaga dan UKM Unand dan bekerja sama dengan BPBD Kota Padang sebagai upaya mitigasi salah satunya dengan membuat program Hari Kesiapsiagaan Bencana Nasional.

Kampus Unand telah melakukan kegiatan simulasi bencana gempa bumi dan tsunami. Akan tetapi, tidak semua mahasiswa terlibat, sehingga kegiatan tersebut dipandang kurang efektif dalam meningkatkan pemahaman mahasiswa dan tenaga pendidik di ruang lingkup kampus Unand akan langkah-langkah mitigasi dan penerapanya. Dan hal ini semakin diperparah dengan minimnya ramburambu dan banner yang diberisikan informasi keselamatan dan evakuasi mandiri pada saat bencana terjadi.

c. Partisipasi Mahasiswa dalam Program Mitigasi

$$
\text { Dalam melaksanakan }
$$

kegiataan mitigasi sebagai salah satu bentuk upaya pengurangan resiko bencana dibutuhkan peran serta masyarakat pada setiap program mitigasi yang telah dibuat oleh pemerintah maupun pihak kampus. Partisipasi mahasiswa merupakan salah satu bentuk dari kesadaran serta kepedulian masyarakat terhadap bencana yang kapan saja bisa terjadi.

Melalui partisipasi terhadap kegiatan mitigasi makan akan merubah pemahaman mahasiswa bahwa bencana memang tidak bisa ditebak kapan akan terjadi dan melalui kegiatan mitigasi mahasiswa atau masyarakat berupaya untuk dapat mengurangi resiko yang ditimbulkan oleh bencana tersebut. Karena dalam pelaksanaan pengurangan resiko bencana mahasiswa merupakan aktor dan pihak yang paling penting. Ketika mahasiswa atau masyarakat ikut berpatisipasi dalam kegiatan mitigasi maka akan mendorong pemahaman mereka terhadap resiko bencana pada lingkungan tempat mereka belajar dan menuntut ilmu serta memahami apa yang harus mereka lakukan jika terjadi bencana.

Berdasarkan teori mitigasi menurut William Nick Carter pada aspek kesadaran masyarakat dibutuhkan kesadaran atau pemahaman tentang kerentaan wilayah yang menjadi pemukiman masyarakat tersebut. Dalam penelitian ini, dimana objeknya diubah menjadi mahasiswa, peneliti menemukan bahwa sebagian besar mahasiswa Unand tidak terlalu memahami potensi gempa dimana daerah kampus tersebut dilalui oleh lempengan yang rawan gempa. Faktor geografis dimana kampus Unand berada di lokasi yang tinggi dan malah menjadi lokasi evakuasi warga kota Padang apabila terjadi gempa dan tsunami, menurut peneliti menjadi alasan utama lengahnya mahasiswa dalam memahami dan menyadari bahwa hal tersebut tidak mempengaruhi besarnya bahaya bila terjadi gempa bumi.

Kemudian yang kedua adalah dapat dilihat melalui pemahaman mahasiswa terhadap langkah-langkah mitigasi beserta pemahamannya. Karena untuk melakukan kegiatan mitigasi W.N Carter menyatakan bahwa mahasiswa terlebih dahulu harus paham apa itu mitigasi dan langkah-langkah yang diberikan harus mudah dipahami oleh mereka. Untuk hal ini peneliti melihat bahwa 
secara umum mahasiswa Unand memiliki pengetahuan yang lumayan dalam hal memahami langkahlangkah mitigasi. Pengetahuan dasar mitigasi seperti berkumpul di tempat terbuka pada saat terjadi gempa, memang telah mereka ketahui. Hal ini akan makin sempurna andaikan penempatan informasi mitigasi bencana seperti banner, ramburambu dan lain sebagainya, lebih merata di berbagai titik keramaian di area kampus.

Selanjutnya yang ketiga yaitu, mitigasi dapat dilakukan apabila mahasiswa ikut berperan aktif dalam melaksanakan mitigasi. Karena menurut W.N Carter untuk melakukan mitigasi secara optimal sangat dibutuhkan masyarakat yang berpartisipasi pada program mitigasi. Pada tahapan ini peneliti melihat untuk partisipasi mahasiswa cenderung masih rendah. Proses sosialisasi berbagai kegiatan mitigasi yang pernah dilakukan, seperti simulasi gempa yang dilakukan oleh KOSBEMA, terlihat tidak berjalan maksimal. Informasi mengenai kegiatan-kegiatan tersebut tidak tersalurkan dengan baik, sehingga mayoritas mahasiswa tidak pernah mengetahuinya. Ini yang kemudian menyebabkan rendahnya tingkat partisipasi mahasiswa terhadap pelaksanaan mitigasi bencana. Artinya, berbagai organisasi atau lembaga yang concern terhadap tema bencana, kurang maksimal dalam meningkatkan kewaspadaan terhadap gempa bumi dalam lingkup kampus Unand.

4. Pelatihan dan Pendidikan

Terhadap Mitigasi Bencana

Menurut W.N Carter dalam melakukan pelatihan dan pendidikan terkait mitigasi bencana kepada masyarakat harus menggunakan metode yang mudah dipahami dan dikenal secara luas oleh masyarakat.
Pada pelaksanaannya, lembagalembaga dalam lingkup Unand mengadakan berbagai acara pendidikan dan pelatihan sebagai edukasi soal mitigasi bencana. Dalam berbagai kegiatan tersebut, mereka menggunakan metode yang mengutamakan penggunaan bahasa dan komunikasi yang mudah dipahami. Namun di samping itu, masing-masing organisasi juga kerap didampingi oleh bermacam-macam lembaga lain, seperti LSM dan instansi pemerintah, yang terlibat kerjasama di acara-acara tersebut. Dari beberapa pelatihan tersebut, beberapa diantaranya cukup gemilang. Seperti pelatihan kepada para pekerja bangunan mengenai cara membangun rumah aman gempa. Hasil pelatihan tersebut hingga sekarang telah menjadi standar yang juga digunakan oleh berbagai lembaga lain yang concern dibidang mitigasi bencana.

5. Insentif

Insentif disini maksudnya adalah subsidi atau pendanaan yang diperoleh masing-masing lembaga mitigasi bencana di kampus Unand. Melalui insentif ini, maka diharapkan dapat mendorong agar kegiatankegiatan mitigasi berjalan lancar. Karena setiap lembaga atau organisasi membutuhkan pendanaan dalam setiap operasionalnya. Apalagi ketika melaksanakan berbagai kegiatan dan acara bertemakan mitigasi bencana, yang melibatkan banyak pihak.

Menurut W.N. Carter, adanya insentif menjadi pendorong berjalannya program mitigasi bencana. Pada masing-masing lembaga tersebut, secara struktural PSB Unand merupakan lemabaga kajian yang didirikan kampus Unand sebagai pusat rieset dan kajian dibidang kebencanaan. Hal ini 
menjadikan pendanaan mereka langsung dari hibah pihak Unand. Sedangkan KOSBEMA disejajarkan sebagai lazimnya UKM yang memperoleh hibah dana sekali per semester dari kampus. sementara, HET yang menjadi organisasi khas fakultas Kedokteran Unand mendapat pendanaan dari pihak dekanatnya, serta sumbangan para alumni.

\section{Sistem Peringatan Dini}

Sistem peringatan dini adalah serangkaian kegiatan pemberian peringatan sesegera mungkin kepada masyarakat tentang kemungkinan terjadinya bencana suatu tempat oleh lembaga yang berwenang. Sistem peringatan dini menjadi hal yang perlu diperhatikan ketika terjadi bencana. Salah satu yang mempengaruhi dalam upaya pengurangan resiko bencana adalah apakah sistem informasi yang diberikan dapat dan mudah dipahami. Sistem peringatan dini yang mudah dipahami disini maksudnya adalah sistem peringatan yang dapat diakses dan dimengerti oleh setiap orang yang melihatnya. Sistem peringatan juga dipengaruhi oleh beberapa variabel, seperti ketersediaan sumber daya dan teknologi.

Berangkat dari teori mitigasi W.N Carter terkait dengan kegiatan evakuasi dibutuhkan sistem peringatan dini yang mudah dan gampang diakses. Lalu kemudian, apakah sistem yang digunakan sudah efisien untuk menjangkau semua lini yang ada pada lingkungan tersebut. Dari yang peneliti temui, terlihat bahwa pemasangan berupa ramburambu evakuasi gempa belum tersedia secara optimal. Masih banyak titik-titik tertentu yang dipandang vital, tapi belum dipasangi oleh rambu-rambu ataupun informasi evakuasi. Di sisi lain, inisiatif beberapa pihak kampus yang menetapkan mata kuliah wajib mitigasi bencana pada kurikulum perkuliahannya, juga dapat dipandang sebagai usaha untuk peringatan dini, karena upayanya dalam memberi kesadaran dan kewaspadaan melalui ilmu dan wawasan yang dipelajari oleh mahasiswa terhadap mitigasi bencana. Hal ini merupakan solusi jangka panjang agar sistem peringatan dini selaras dengan peningkatan ilmu pengetahuan akan musibah bencana alam.

\section{KESIMPULAN}

Berdasarkan penjelasan temuan dan analisis dapat peneliti simpulkan bahwa secara umum berbagai lembaga kajian dan tanggap bencana telah didirikan oleh pihak Universitas Andalas. Namun, beberapa kegiatan yang mereka lakukan masih belu meraih sasaran, berupa adanya peningkatan kewaspadaan bencana serta pemahaman atas mitigasi bencana kepada mahasiswa dan civitas akademika. Sementara itu, regulasi yang jelas mengenai landasan hukum juga belum jelas dan masih menjadi tugas yang terbengkalai.

Kemudian

untuk mempermudah pelaksanaan mitigasi bencana, pihak kampus Unand telah membentuk berbagai lembaga yang berasal dari civitas akademika, baik dari kalangan mahasiswa atau dosen, untuk membantu melaksanakan mitigasi serta bertujuan untuk meninngkatkan pengetahuan masyarakat dalam proses mitigasi. Dalam implementasinya, lembagalembaga tersebut sudah berusaha memberikan fungsi yang nyata dalam berbagai kegiatannya. Hal tersebut dapat dilhat dari berbagai kegiatan seperti pelatihan, seminar dan simulasi gempa. Ragam kegiatan tersebut mengarahkan kepada 
masing-masing lembaga untuk juga menjalin kerjasama dengan berbagai pihak.

\section{REFERENSI}

Carter, W. N. 2008 Disaster Management: A Disaster Manager's Handbook, Mandaluyong City, Manila: Asian Development Bank

Evi,Riene dkk. 2009. Buku Pintar Gempa. Yogyakarta: Diva Press

Kusumasari, Bevaola, Manajemen Bencana dan Kapabilitas Pemerintah Lokal, Yogyakarta: Gava Media, 2014

Khambali, Manajemen

Penanggulangan Bencana, Yogyyakarta: CV. Andi

Moleong J,Lexy, Metodologi Penelitian Kualitatif, PT Remaja Rosdakarya, Bandung, 2000

Putera, Roni Ekha ,Mitigasi Pengurangan Risiko Bencana Gempa Bumi Dari Perspektif Implementasi Kebijakan. Depok: PT RajaGrafindo Persada,2018

Pasalong,Harbani Metode Penelitian Adminitrasi Publik, Alfabeta, Bandung, 2012

Ramli,Soehatman. 2010. Pedoman Praktis Manajemen Bencana (Disaster Management). PT Dian Rakyat:Jakarta

Sudarmi Sri, Waluyo, Galeri Pengetahuan Sosial Terpadu, 2008, Semarang : PT. Sindur Press

Sugiyono, Metode Penelitian Kuantitatif Kualitatifdan R\&D, Alfabeta, Bandung, 2012
Alim, Nuzuar. 2017. Analisis Kesiapsiagaan Masyarakat Dalam Menghadapi Ancaman Bencana Gempa Bumi dan Tsunami Di Kecamatan Padang Barat Kota Padang Tahun 2017. Skripsi. Padang: Fakultas Kesehatan Masyarakat Universitas Andalas.

Sijabat Pangihutan Thogap, Kriswanto. 2019. Kapabilitas Pemerintah Kota Padang dalam Mitigasi Bencana Melalui Sekolah Cerdas Bencana. Skripsi. Fakultas Ilmu Sosial dan Ilmu Politik. Universitas Andalas

Sari Anita,Dwi 2017. Peran Pemerintah Daerah Dalam Upaya Rehabilitas dan Rekontruksi Pasca Bencana Banjir di Kabupaten Sampang, Skripsi. Malang : Fakultas Ilmu Sosial dan Ilmu Politik Universitas Muhammadiyah Malang.

Wialdi, Putri Febri. 2020. Mitigasi Bencana Gempa Bumi dan Tsunami Berbasis Kearifan Lokal Masyarakat Pesisisr Pantai Kota Padang. Skripsi. Padang: Fakultas Ilmu Sosial dan Ilmu Politik Universitas Andalas 